\title{
Uma relação concreta: A prática do futebol em São Paulo e os Estádios do Parque Antarctica e do Pacaembu
}

\author{
Fernando Atique ${ }^{1}$ \\ Diógenes Sousa ${ }^{2}$ \\ Hennan Gessi ${ }^{3}$
}

RESUMO: Ao relacionar a introdução do futebol na cidade de São Paulo, seu desenvolvimento e a atração de torcedores, o artigo procura mostrar como esta prática esportiva tornou-se não apenas cultural, mas também material na Pauliceia. De maneira específica, o artigo analisa como dois dos principais estádios paulistanos foram forjados, e como as arquiteturas do Parque Antarctica, na Água Branca, e do Pacaembu, no bairro homônimo, possibilitaram o desenvolvimento e a celebração de uma tecnologia construtiva: a do concreto armado. $\bigcirc$ artigo explora, então, alguns caracteres de identidade da capital paulista: o futebol e o concreto armado, tecendo considerações sobre esta relação indelével, embora pouco explorada em nossa historiografia.

PALAVRAS-CHAVE: Futebol. Concreto Armado. Parque Antarctica. Pacaembu. São Paulo. Estádios.

ABSTRACT: Relating the introduction of soccer in the city of São Paulo, its development and the attraction of fans, the paper aims to show how this Sport can be seen not only as a cultural manifestation, but also, as a material contribution for the city. In a specific way, as the main goal, the paper analyzes the conformation of two Stadiums: the Parque Antarctica, built in the Água Branca neighborhood, and the Pacaembu, erected in the homonymous neighborhood. These stadiums, as notable architectures, served as passports to a celebration: the Reinforced Concrete Technology as a symbol of São Paulo. As a final contribution, the article discusses the Paulista identity from those elements: the soccer and the reinforced concrete, showing the hard ties between them, curiously almost nonexistent in our historiography.

KEY-WORDS: Soccer. Reinforced Concrete. Parque Antarctica. Pacaembu. São Paulo. Stadiums.

\begin{abstract}
1. Arquiteto e urbanista, mestre em Teoria e História da Arquitetura e doutor em História e Fundamentos Sociais da Arquitetura e do Urbanismo pela USP. É professor na graduação e na pós-graduação do Departamento de História da Universidade Federal de São Paulo, e coordenador do Grupo de Pesquisa CAPPH - Cidade, Arquitetura e Preservação em Perspectiva Histórica. E-mail:<fernando.atique@ unifesp.br>.
\end{abstract}

2. Historiador pela Universidade Federal de São Paulo. Atualmente, cursa o mestrado em Urbanismo na Pontifícia Universidade Católica de Campinas, ao abrigo de bolsa CAPES. E-mail: <diogenesudi@hotmail. com>.

3. Historiador pela Universidade Federal de São Paulo. Atualmente, cursa o mestrado em História e Historiografia na Universidade Federal de São Paulo, ao abrigo de uma bolsa FAPESP. É pesquisador do Grupo CAPPH. E-mail: <hennan. gessi@gmail.com>. 
4. Ver John R. Mills (1996, p.41).

5. Os primeiros contatos dos religiosos jesuítas com o futebol, conforme Santos Neto, parecem ter acontecido quando das excursões que realizavam para escolas europeias, no século XIX, a fim de obterem formações complementares para a alfabetização de crianças brasileiras. Ver José Moraes dos Santos Neto (2002, p.1315).

6. Ver John R. Mills (1996, p.15).

7. Charles Willian Miller nasceu em São Paulo em 1874. Descendente de britânicos foi para Inglaterra estudar com dez anos de idade, entrando em contato com diversos esportes locais. Em 1894, retornou ao Brasil para trabalhar na Empresa São Paulo Railway, mas também com a intenção de difundir suas experiências esportivas vivenciadas em solo inglês. Miller foi vice-cônsul inglês em 1904. Faleceu em 1953. Ver John R. Mills (1996, p.917).

8. Ver Ibidem (p.23).
Uma Relação Concreta: A Prática do Futebol em São Paulo e os Estádios do Parque Antarctica e do Pacaembu

Que a paisagem paulistana é marcada por estruturas de concreto é um fato indiscutível. Arranha-céus, postes, pontes, viadutos são facilmente identificados pelas ruas da cidade. Mas como a tecnologia deste material de construção favoreceu o desenvolvimento esportivo da cidade ainda é algo não discutido com grande ênfase em nossa historiografia. Este artigo reúne, então, considerações sobre a íntima relação entre a prática esportiva do futebol e o emprego do concreto armado, mostrando como a ideia de robustez, solidez e modernidade atribuídas ao concreto nas primeiras décadas do século XX, em igual medida permearam os discursos da construção de dois dos principais espaços esportivos da cidade: os estádios do Parque Antarctica e do Pacaembu. Convém, então, mostrar como a expansão da prática desse esporte de massas na capital paulista gerou demandas que impulsionaram o emprego de grandes estruturas de concreto nesses estádios e ajudaram a produzir mais uma das imagens associadas à cidade de São Paulo: a de uma cidade de concreto.

A introdução do futebol em São Paulo e os primeiros espaços de sua prática

A visão mais tradicional sobre a história do futebol parte do pressuposto de que Charles Miller foi o seu introdutor. Essa narrativa ainda apresenta a alegação de que antes de sua chegada ao país, em 1894, o esporte não havia sido difundido e organizado por aqui ${ }^{4}$. A "paternidade" da introdução do futebol atribuída a Miller é refutada por estudiosos contemporâneos devotados à história do futebol. Um desses autores, José Moraes dos Santos Neto, em sua obra Visão do jogo: os primórdios do futebol no Brasil, expõe a tese de que, desde os anos 1880, muitos colégios de elite - sobretudo os dirigidos por jesuítas, como o São Luís, estabelecido, na época, na cidade de ltu - já haviam introduzido o esporte na grade curricular ${ }^{5}$. De fato, nos primórdios do futebol em São Paulo, o papel fundamental de Charles Miller foi ter iniciado a prática da Association football, surgida na Inglaterra, em 1863, pela necessidade da padronização do jogo que possuía regras distintas entre as escolas britânicas ${ }^{6}$. Em 1884, Charles Willian Miller, de família britânica, viajou à Inglaterra para completar seus estudos. Miller instalou-se na cidade de Southampton, no condado de Hampshire, para frequentar a escola Banister Court School, tradicional, inclusive, na prática esportiva. Durante o tempo em que passou no país, jogou críquete, rúgbi e conheceu, e destacou-se, no futebol$^{8}$. Depois de dez anos na Inglaterra, Charles Miller retornou ao Brasil trazendo na bagagem equipamentos de futebol e um livro de regras, com a intenção de continuar praticando o esporte e angariar novos adeptos. Sócio do São Paulo Athletic Club (SPAC), fundado em 1888, Miller, em 1896, organizou e participou do primeiro time de futebol formado por sócios do clube, ingleses e descendentes, que possuíam altos cargos em instituições com capital britânico, como a Companhia de Gás e a ferroviária The São Paulo Railway Co Ltd. 
Já em 1898, foi fundada a Associação Atlética Mackenzie College. Ligado ao Mackenzie College, o time dessa Associação Atlética era composto por jovens jogadores brasileiros. John Mills revela que as atividades esportivas no Mackenzie começaram com o incentivo do professor Augusto Shaw', que desejava, em um primeiro momento, introduzir o rúgbi e o "cestobol", mas pela falta de adaptação dos alunos, acabou decidindo ensinar o futebol ${ }^{10}$.

Dentro da perspectiva da gênese do futebol, o alemão Hans Nobiling "1, um dos fundadores do Sport Club Germânia, foi de grande importância para a "socialização" do esporte bretão em São Paulo. Nobiling enfrentou dificuldades para encontrar adeptos do futebol na comunidade alemã paulistana, pela preferência dessa à ginástica. No entanto, não desistiu de formar uma equipe, reunindo-se com outros interessados de diversas nacionalidades, dentre eles, brasileiros e ingleses, culminando na formação do Sport Club Internacional em 1899. Após desentendimentos em relação ao nome do clube, Nobiling fundou o Sport Club Germânia com outros compatriotas ${ }^{12}$.

Curioso é apontar que antes mesmo da deflagração do futebol na capital paulistana, a elite local já dispunha de espaços para a prática desportiva, como atesta a criação do Jockey Club - então Club de Corridas Paulistano formado em 1875 e instalado um ano depois, no bairro da Mooca, zona leste da cidade, por Rafael Aguiar Paes de Barros, que chegou a ser vereador pelo Partido Republicano Paulista. Nos anos finais do século XIX, São Paulo teria ainda outro hipódromo, no vizinho bairro do Brás, chamado Derby Club. Além do turfe, o remo se desenvolveria ao fim do século XIX, tendo como expoentes o Clube de Regatas Santista e o Clube Internacional de Regatas, em 1893 e 1897, respectivamente, ambos na cidade de Santos. Na capital, o Clube Esperia, em São Paulo, é formado em 1899, realizando suas provas no rio Tietê, juntamente com o Clube de Regatas Tietê. A bicicleta ou velocípede, também na década de 1890, ganhou um caráter mais desportivo a partir das primeiras corridas, algumas delas feitas pelo Esporte Clube Internacional, mas, em especial, no Velódromo Paulista.

Veridiana Valéria Prado, proprietária do antigo Velódromo Paulista, instalado na região da Consolação, na capital, acabou, curiosamente, sendo elevada à categoria de patronesse informal do futebol. Isso porque um dos fundadores do Club Athlético Paulistano ${ }^{13}$, Antônio Prado Júnior, depois de negociar com sua avó, conseguiu instituir a antiga chácara da família como sede desse clube. Como aponta Wilson Roberto Gambeta:

Quando o velódromo foi construído, em 1895, o arruamento urbano já avançava nas imediações e o trecho inicial da antiga estrada se convertera na rua da Consolação. A chácara abrangia uma área de tamanho considerável, se comparada aos padrões urbanos atuais. Na largura chegava até o vale do ribeirão Saracura (atual avenida Nove de Julho) e no comprimento ia até o local onde foi construído, em 1878, o reservatório de águas da Companhia Cantareira (situado na esquina da atual rua Dona Antonia de Queirós). A sede era um grande sobrado edificado no século XVIII, alinhado com a estrada como era costuma na arquitetura colonial ${ }^{14}$.
9. Nascido em Clayville, região de Nova York. Quando chegou ao Brasil, em 1896, além de divulgar o futebol, introduziu e difundiu o basquete no país. Shaw viveu no Brasil até 1914. Faleceu em 1939, nos Estados Unidos. Ver <www.educacaofisica.seed.pr.gov.br/modules/conteudo/conteudo. php?conteudo $=473 \mathrm{>}$. Acesso em $1^{\circ}$ mar. 2015.

10. Ver John R. Mills (1996, p.42).

11. Nascido em Hamburgo, em 1877. Foi Jogador de futebol e um dos fundadores do Sport Club Germânia, atualmente Esporte Clube Pinheiros. Juntamente com Charles Miller foi um dos precursores do futebol em São Paulo. Faleceu em 1954. Ver John R. Mills (1996, p. 47).

12. Ver John Mills (1996, p.47).

13. Fundado em 1900, o Club Athlético Paulistano procurava desenvolver não apenas o futebol, mas, antes, possuía a intenção de ser um espaço de convivência das elites na prática de variadas formas de lazer propício à burguesia.

14. Cf. Wilson Roberto Gambeta (2014, p.71). 
15. Gambeta deixa claro que o empreiteiro Pedro Macaggi, em ofício datado de 09 de março de 1886 , trabalhou em uma reforma do Velódromo. Aponta o mesmo autor que a pista do Velódromo foi "cimentada" em finais da década de 1890. Cf. Wilson Roberto Gambeta (2014, p.74).

16. Cf. Cf. Wilson Roberto Gambeta (2014, p.74).

17. Cf. John R. Mills (1996, p.41).

18. Ibidem (p.52).

19. Ver Wilson Roberto Gambeta (2014, p.67).
Gambeta, analisando o cenário esportivo paulistano no século XIX, mostrou que as instalações esportivas dedicadas ao turfe e mesmo às bicicletas, como as do Velódromo, eram erigidas em madeira, de maneira assemelhada às encontradas na Europa e nos Estados Unidos. O concreto armado não era, como sabemos, material de construção naquele momento, prestando-se antes às atividades de infraestrutura urbana ${ }^{15}$. Mas algumas informações dadas por Gambeta mostram como, pouco a pouco, esse material passou a ser empregado nos espaços esportivos. O Conselheiro Antonio Prado contratou Tommaso Gaudenzio Bezzi arquiteto italiano radicado na cidade e um dos autores do edifício que hoje abriga - Museu Paulista - para conceber outros conjuntos de arquibancadas, ainda em madeira. Depois, o empreiteiro Giuseppe Valori executou oficinas, camarotes, dentre outros melhoramentos, que incluíram um rinque de patinação e um campo de futebol, no centro da pista, nas palavras de Gambeta, "um pouco menores do que as recomendadas pelas regras inglesas." ${ }^{16}$. Assim, o Velódromo Paulista, inicialmente construído para o ciclismo, passou a ser palco do futebol paulista, tornando-se um símbolo dos primórdios desse esporte na cidade.

O ano de 1900 foi, ainda, marcado pelo retorno a São Paulo de Antonio Casemiro da Costa, definido por John Mills como o "organizador do futebol bandeirante"17. Costa, assim como Miller, foi à Europa para um período de estudos e acabou conhecendo o futebol. Ao retornar a São Paulo, filiou-se ao Sport Club Internacional, mas se aproximou dos outros principais clubes que praticavam esse esporte. Em 1901, os clubes paulistas, principalmente pelo intermédio de Costa e outros integrantes do Sport Club Internacional, como Rene Vanorden, estreitaram ainda mais as relações. Isso reflete-se, sobretudo, nos embates organizados por Vanorden e os irmãos Oscar e Sidney Cox, precursores do futebol no Rio de Janeiro entre paulistas e cariocas. $O$ selecionado de São Paulo contava com jogadores dos cinco principais times da cidade, que formaram a primeira Liga Paulista de Futebol ainda em dezembro do mesmo ano ${ }^{18}$.

Antonio Casemiro da Costa foi definido como primeiro presidente da Liga, tendo como vice Hans Nobiling, do Germânia. John Mills relata que a organização do campeonato ficou por conta, principalmente, de Costa, que definiu as sedes, o plano de divulgação à imprensa, os uniformes e a divisão dos lucros entre os clubes e a nova entidade. O primeiro jogo ocorrev em maio de 1902, no Parque Antarctica, entre o Mackenzie e o Germânia. $\bigcirc$ Parque criado, anos antes, pela Companhia Antarctica Paulista, para comercialização das bebidas que ali eram produzidas, condizia com a realidade social da elite paulistana que necessitava de espaços para a prática do lazer e do esporte que estava por se massificar cada vez mais, já que havia dois campos de futebol. Sua localização privilegiada, com fácil acesso em função da linha de bonde financiada pela própria Companhia, era um atrativo à população paulistana, que para ali acorria com grande frequência. O São Paulo Athletic Club acabou como campeão ao vencer o Club Athlético Paulistano em um jogo desempate ocorrido no Velódromo ${ }^{19}$. Contudo, o que mais se destacou nesse primeiro torneio foi a grande presença de público, chegando, na 
final, em torno de 4000 pessoas $^{20}$. Em 1913 ocorreu uma cisão na Liga de Futebol Paulista, surgindo a APEA - Associação Paulista de Esportes Atléticos -, que em pouco tempo tornou-se a principal entidade do futebol de São Paulo. Esta nova entidade era liderada pelo Clube Paulistano, que havia se desligado da Liga Paulista de Futebol por não concordar com a entrada do Sport Club Corinthians Paulista, time de origem popular ${ }^{21}$. No ano anterior, O SPAC já havia saído da Liga e encerrado a prática futebolística no clube, por considerar que o futebol não era mais o mesmo de antigamente 22 . Percebe-se então que a prática do futebol estava alterando não apenas o lazer da cidade, mas levando, como consequência, a uma redefinição de programas arquitetônicos e urbanísticos na Pauliceia.

O futebol como fenômeno de lazer urbano: times em busca de arquibancadas

A rápida ascensão e popularidade do futebol em São Paulo é fruto de um processo não apenas ligado aos clubes de elite, mas também a seu crescimento entre os menos abastados, dentre eles, em um primeiro momento, estrangeiros que chegavam à cidade para trabalharem nas fábricas e na expansão das ferrovias, como operários ${ }^{23}$. Os primeiros times populares começaram a aparecer em São Paulo na região da Várzea do Carmo, ao lado da principal área da cidade, onde atualmente está estabelecido o Parque Dom Pedro II. Ferreira ${ }^{24}$ aponta que o futebol surgiu na região pouco depois de seu estabelecimento no Velódromo Paulista. $O$ autor revela que trabalhadores de todas as origens começaram a frequentar o local, formando uma porção de times que disputavam campeonatos aos domingos.

Além disso, rapidamente, em outras localidades da cidade surgiram novos campos. Nos bairros operários o futebol já era praticado rotineiramente, e assim como nos jogos da elite, atraíam boa média de público. Ainda nos primeiros anos do século XX despontou o Clube Attético Ypiranga, primeiro clube de origem popular a participar da Liga Paulista de Futebol, em função do grande público que acompanhava seus jogos, o que o tornava um atrativo financeiro para os organizadores ${ }^{25}$.

Alguns episódios ocorridos nos anos 1920 confirmam a contínua expansão do futebol, que, segundo a autora Monica Raissa Schpun, naquela década, tornou-se um dos elementos chaves de afirmação do poder nacional ${ }^{26}$. Um desses episódios que simbolizou o crescimento e a capacidade do esporte bretão em atrair e envolver as massas aconteceu em 1925, protagonizado pelo Paulistano quando realizou uma excursão à Europa. Dos dez jogos disputados, os paulistas venceram nove, sendo surpreendidos com uma recepção triunfal no retorno ao Brasil, como conta Schpun:

Sua volta ao Brasil é celebrada em todos os lugares: o navio para primeiro em Recife, onde a população já espera os jogadores do "glorioso". No Rio, festas oficiais são organizadas para recebê-los: fanfarras militares e cumprimentos oficiais do Presidente da República. Em São Paulo, última etapa da viagem, a cidade praticamente para na chegada do time. Um cortejo de dois mil carros é organizado para trazer os jogadores até a sede do clube, onde uma recepção oficial os espera, mas a multidão acaba carregando-os em triunfo pela cidade. ${ }^{27}$
20. Ver Hennan Gessi (2013).

21. Ver João Pernambuco Ferreira (2008, p.36).

22. Ibidem

23. Ver João Pernambuco Ferreira (2008, p.29) e Hennan Gessi (2013).

24. Ibidem.

25. Ibidem (p.36).

26. Cf. Monica Raissa Schpun (1999, p.71).

27. Cf. Ibidem (p.72). 
28. Cf. A Gazeta (15 maio 1929).
A descrição de Schpun sobre a volta do Paulistano ao país expõe elementos que comprovam a mobilização que o futebol provocou em diversas esferas sociais. Primeiramente, destacam-se as saudações das massas, ocorridas em três estados distintos, evidenciando que o futebol nos anos 1920 já era conhecido em diversas regiões brasileiras, revelando-se como um potencial objeto integrador. Além disso, as fanfarras militares e a recepção presidencial retratam o envolvimento político no cenário futebolístico, parceria que seria cada vez mais explorada pelo governo brasileiro, que passou a enxergar o esporte como um instrumento de manipulação de massas e de exaltação nacionalista.

Outra questão em evidência nesse período era a da infraestrutura dos estádios, não mais compatíveis com o número de espectadores:

O domingo que passou serviu para nos provar que o maior estádio da cidade, o Parque Antartica, não é mais capaz de suportar a grande leva de torcedores. $\bigcirc$ embate entre Palestra e Corinthians levou mais de 35 mil expectadores ao estádio. Quando as autoridades vão olhar mais diretamente para isso? $\bigcirc$ futebol é o mais popular esporte da cidade, e ainda não temos um estádio compatível com essa popularidade. ${ }^{28}$

Alvo de debates desde o final da década de 1920, a construção de um estádio compatível com a dimensão do futebol tornou-se realidade nos anos 1930. Em 1936, o Estádio Municipal do Pacaembu começou a ser construído e o principal esporte brasileiro ganhou um palco propalado como condizente com o seu tamanho. Contudo, o Pacaembu não era fruto apenas do crescimento do esporte bretão, pois, mais do que isso, surgiu por confluência de interesses políticos e privados em conjunto com a expansão urbana registrada em São Paulo, desde o final do século XIX e foi palco privilegiado para a adoção do concreto armado. Todavia, no mesmo período, e ao nosso ver, como reflexo dessa "competição" com o Estádio Municipal, o Parque Antarctica começou a redesenhar seus espaços, valendo-se, portanto, do concreto armado, símbolo de modernidade, embora ainda revestido por ornamentos, muitas vezes, étnicos.

$\bigcirc$ Parque Antarctica e seus projetos

Em 1917, o time formado pela colônia italiana três anos antes, o Palestra ltália, passou a alugar o campo do Parque Antarctica por intermédio do América FC, que já era locatário do mesmo espaço, mas que não podia arcar com todas as despesas do aluguel (Figura 1). $\bigcirc$ novo time italiano fazia sucesso em suas partidas e isso acarretou um número maior de torcedores, motivando a equipe palestrina a comprar a área do Parque em 1920, pelo valor de 500 contos de réis, sendo a metade à vista e o saldo em mais duas prestações de 125 contos de réis, pagas anualmente.

Passada a compra do imóvel, o importante era pensar na construção de um estádio novo. Para isso, a diretoria promoveu um concurso para arquitetos italianos residentes no Brasil ou na ltália para que recebessem seus memoriais com 
as demandas impostas pela diretoria. A vontade em erigir um estádio próprio era imensa, mas isto se consolidou anos mais tarde. $\bigcirc$ ano de 1921 passou-se sem que o interesse pelo projeto atraísse os arquitetos italianos, quer seja pela distância dos que na Itália residiam, quer pelos poucos residentes no Brasil. $\bigcirc$ fato é que, no ano seguinte, o concurso sofreu alterações, tendo sido aberto também aos arquitetos brasileiros, oferecendo uma premiação de 5 contos de réis para o primeiro colocado, 3 contos para o segundo e 2 contos para o terceiro 29 . No primeiro semestre de 1923, foram apresentadas propostas por dezesseis concorrentes, porém, uma cláusula contratual não permitia ao Palestra investir mais que 1500 contos de réis na obra, o que reduziu o número de projetos para seis firmas. Participaram da concorrência os escritórios de Fernando Malgarini, de Milão e de Raul Penafirme, do Rio de Janeiro, os únicos forâneos, já que os demais eram todos de São Paulo. A comissão julgadora foi formada pelos arquitetos Ramos de Azevedo30 (1851-1928) e Victor da Silva Freire ${ }^{31}$ (1869-1951), pelo pintor Antonio Rocco ${ }^{32}$ (1 880-1944) e pelo escultor Nicola Rollo33 (1889-1970), todos atuantes em São Paulo, além do escultor turinense, Alfonso Chioccarello (18? 1962) 34. Sob o pseudônimo de "Spartaco" (Figura 2), venceu o certame o projeto do arquiteto Ettore Battisti. $\bigcirc$ projeto premiado era vazado em estilo mourisco, já empregado por Battisti em outras obras em São Paulo ${ }^{35}$. Com forma e ornamentações evocativas do universo cultural espanhol, pouca relação guardava com a suposta identidade italiana perseguida pela agremiação. Contudo, questões orçamentárias e problemas administrativos não permitiram a execução da obra. Em todo o caso estava lançada a centelha para a realização do empreendimento.

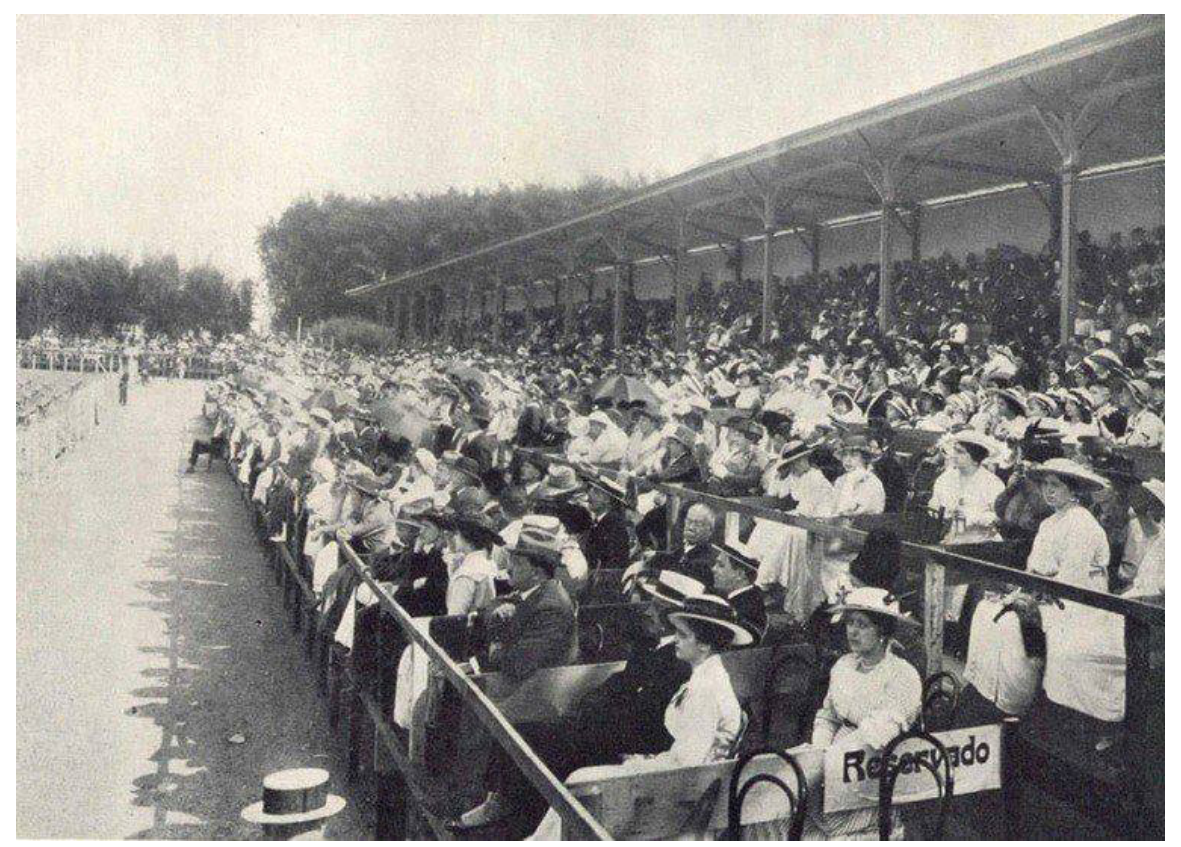

Figura 1 - Dia de jogo no Parque Antarctica, em 1914, mesmo ano de fundação do Palestra ltália. Notar as arquibancadas e a marquise executadas em madeira. Acervo de Fernando Atique.
29. Ver Diógenes Sousa (2014).

30. A concentração de arquitetos italianos no Escritório Técnico Ramos de Azevedo é algo já debatido pela historiografia. Ver, a respeito, Carlos Lemos (1993); Maria Cristina Wolff de Carvalho (1999); Ana Paula Farah (2003).

31. Freire, conforme Luiz Augusto Maia Costa, casouse com a italiana Francisca Rizzo Freire. Ver Luiz Augusto Maia Costa (2011, p.2).

32. Nascido em Amalfi, em 1880, imigrou ao Brasil em 1913. Destacado pintor de paisagem, lecionou em São Paulo, na Escola Novíssima, da qual era um dos sócios fundadores. Representou o Brasil em algumas exposições na Itália. Faleceu em São Paulo, capital, em 1944. A respeito de sua biografia, ver <www.itaucultural.org. br/aplicExternas/encicloped i a - I C / i n d e x cfm?fuseaction=artistas b i o g r a f i a \& c d verbete $=1124 \&$ cd_idio$\mathrm{ma}=28555>$. Acesso em 24 mar 2015.

33. Nascido em Bari, em 1889, parece ter aportado no Brasil em 1913. Foi professor da Escola de Belas Artes de São Paulo a partir de 1933, e, antes, do Liceu de Artes e Ofícios de São Paulo. Obteve o terceiro lugar no concurso para o Monumento da Independência, instalado no Ipiranga, em 1919, o que causou a revolta de alguns articulistas de jornal, como Monteiro Lobato, que requisitavam a vitória a Rollo. O que chama a atenção é seu destaque no cenário artístico paulista nos anos 1920. A respeito de sua biografia, ver <https:// pt.wikipedia.org/wiki/Nicola_Rollo $>$. Acesso em 24 mar 2015.

34. Pouco sabemos sobre Alfonso Chioccarello. A in- 
formação encontrada de maior crédito diz acerca de seu trabalho na Paróquia Santo Alfonso, em Turim. Ver <www.parrocchia santalfonso-torino.it/opere_arte.php>. Acesso em 20 mar. 2015. Parece que sua passagem por São Paulo foi rápida, talvez por demanda do próprio Palestra Itália, que pretendia construir um estádio com projeto italiano. Encontramos a data de seu falecimento, em Turim, em 06 de agosto de 1962, ver $<$ www.inmiamemoria.com/ scatole_dei_ricordi/Chioccarello/Alfonso/>. Acesso em 25 mar 2015.

35. Ver Marlene Milan Acayaba (2013).

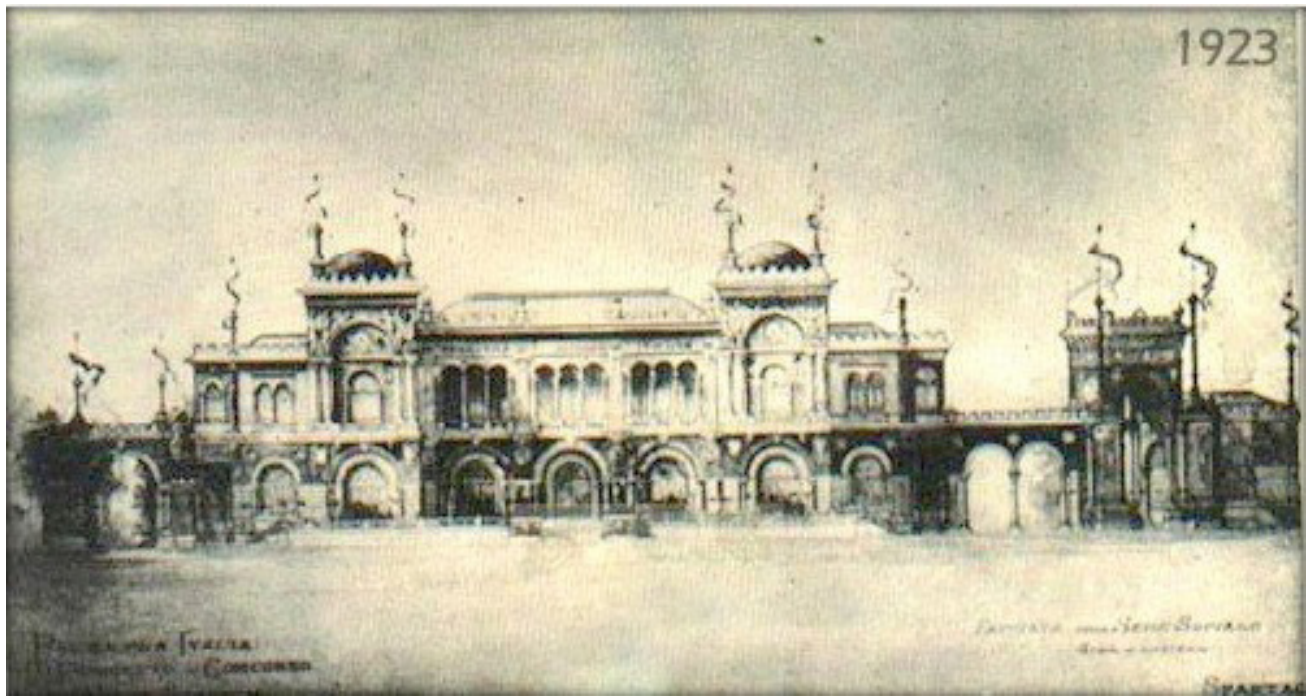

Figura 2 - Proposta de Ettore Battisti com referência mourisca. Spartacus, apresentada no concurso fechado promovido pelo Palestra Itália. Acervo da Sociedade Esportiva Palmeiras.

É possível distinguir, de acordo com a reformulação do estádio, um processo que demonstra um novo conceito na construção civil, em que o carro-chefe era o concreto armado e suas aplicações nas mais diversas formas, como a construção da tribuna social e das arquibancadas que substituiriam as anteriores feitas de madeira, proporcionando melhores condições para um número maior de torcedores, muitos deles chegando ao estádio pelos bondes que saíam do centro da cidade. As novas arquibancadas foram inauguradas em 13 de agosto de 1933, durante a partida de Palestra ltália versus Bangu, pelo Torneio Rio-São Paulo. Nesta mesma ocasião, o estádio passou a chamar-se Stadium Palestra ltália nome que já era popularmente usado. Apresentava-se ao público, então, o "maior e mais moderno estádio de futebol do país", segundo dizeres da época. Epíteto este que seria mantido até a inauguração do Estádio Municipal do Pacaembu, em 1940.

Por volta de 1935, a sede social do clube foi transferida do centro da cidade para o entorno do estádio. Esta mudança acarretou em ampliação efetiva das dependências, pois começaram a ser ocupados espaços abaixo das arquibancadas para sala de troféus e partes do setor administrativo. A preocupação com o desenvolvimento patrimonial mostra-se com a ampliação do estádio, ocorrendo mais uma vez em 1936. Com a festa da inauguração da Tribuna Vitalícia e de Honra, ergue-se um novo bloco de concreto armado ligando-se aos construídos em 1933, para que embaixo se instalassem restaurante e salão de festas. $\mathrm{Na}$ década de 50, uma nova reforma foi realizada seguindo-se projeto do engenheiro Clovis Felipe Olga, que propôs a união das duas arquibancadas em forma de "U" perfazendo uma "ferradura" e criando um novo lance de arquibancadas acima destas, levando, assim, à acomodação de um número ainda maior de torcedores nos dias de jogos. 
Contudo, a tecnologia do concreto armado empregada por Olga promoveu aquela que foi, sem dúvida, uma das reformas mais impactantes sofridas pelo Estádio Palestra Itália. $\bigcirc$ córrego da Água Branca corre em tubulações sob a Avenida Sumaré, juntando-se ao córrego da Água Preta, cuja nascente fica no bairro da Pompéia, desaguando no rio Tietê. Não é preciso muita chuva para que a região lindeira ao Palestra Itália sofra, ainda hoje, as consequências provocadas pelas enchentes. A solução encontrada pela equipe de Olga foi elevar o patamar do gramado para que este não fosse prejudicado em caso de cheias. Sendo assim, o campo de futebol ficou elevado dois metros e meio em relação ao solo, tornandose conhecido como os "Jardins Suspensos de Palestra Itália" (Figura 3). Abaixo do campo ficaram os vestiários dos jogadores, um ginásio com cine-auditório e outros departamentos de esportes amadores, almoxarifado e manutenção. A reinauguração do estádio deu-se no dia 7 de setembro de 1964, em uma partida válida pelo Campeonato Paulista, com vitória do Palmeiras - o então Palestra Itália teve de mudar seu nome em 1942, por decreto do Presidente Getúlio Vargas, em função da Segunda Guerra Mundial - sobre o Guaratinguetá, por 2x0.

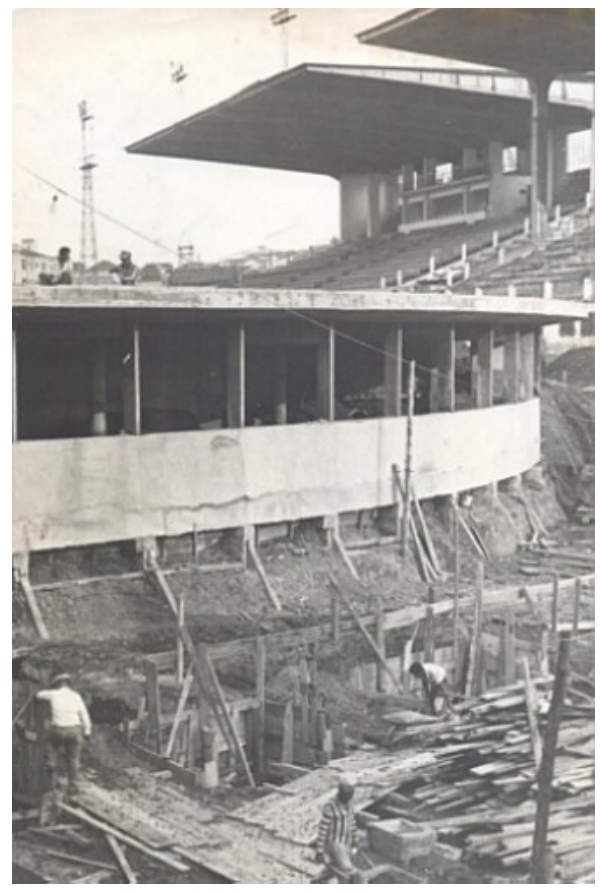

Figura 3 - A solução espacial empregada por Clovis Felipe Olga, nos anos 1960, para ampliação e estanqueidade às cheias sofridas pela área, a qual redundou no epíteto de "Jardins Suspensos do Palestra Itália". Acervo da Sociedade Esportiva Palmeiras.

\section{Estádio Municipal do Pacaembu}

Como já afirmado, a cidade de São Paulo viveu, entre 1870 e 1930, um período de efervescência e transformações em diversos setores, dentre eles, econômico, urbano e político, os quais propiciaram a entrada de novos investidores na cidade como a Cia City of São Paulo Improvements and Freehold Land Co Ltd., formada na capital paulista em março de $1912^{36}$.

36. Ver Cristina Peixoto Mehrtens (2010). 
37. Nascido em Chesterfield, em 1867. Destacado arquiteto no campo do urbanismo, Parker foi membro do movimento pela Cidade-Jardim. Chegou ao Brasil na década de 1910 e participou dos projetos de implantação dos bairros paulistanos do Pacaembu, Jardim América, Alto da Lapa, entre outros. Faleceu em 1947. A respeito de sua biografia, consultar <http:// www.spartacus.schoolnet. co.uk/Barry_Parker.htm>. Acesso em $1^{\circ}$ mar. 2015.

38. Cf. Cristina Peixoto Mehrtens (2010).

39. Ver ibidem (p.140). Em 1936, a Cia City doou mais 25.598 metros quadrados a pedido do município para o desenvolvimento da obra do Estádio do Pacaembu. Ver Hennan Gessi (2013, p.27).

40. Ibidem.

41. Cf. Cristina Peixoto Mehrtens (2010, p.141).

42. Arnaldo Dumont Villares nasceu em São Paulo, em 1888. Casou-se com Laura Lacaze Ramos de Azevedo, filha de Ramos de Azevedo, em 1912. Foi engenheiro e consequentemente diretor do então Escritório Ramos de Azevedo, após a morte de seu sogro, em 1928. O nome do Escritório Ramos de Azevedo acabou substituído por Severo Villares na década de 1930. Arnaldo Dumont Villares participou ativamente das negociações para a implantação do projeto de construção do Estádio Municipal do Pacaembu. Faleceu em 1965. Ver Anamaria Germano Ribeiro (1998.).
A Cia City modificou a magnitude da atividade imobiliária em São Paulo, desenvolvendo projetos, sobretudo para a elite, instituindo os bairros jardins na cidade, que valorizavam a estrutura fundiária dos terrenos adquiridos. $\bigcirc$ responsável pelo desenvolvimento desse padrão urbanístico foi o arquiteto inglês Richard Barry Parker ${ }^{37}$, que chegou ao Brasil, contratado pela City, em 1915. A Companhia inglesa adquiriu terrenos em todas as regiões da cidade, no entanto, seus principais projetos foram desenvolvidos na porção sudoeste, onde se localiza o bairro do Pacaembu.

Inicialmente, por ser uma área de difícil acesso, a região do Pacaembu permaneceu praticamente desocupada. Porém, o bairro era considerado atraente devido à sua localização próxima ao centro e por ser lindeiro ao já elitizado bairro de Higienópolis. Na década de 1910, quando Parker chegou a São Paulo e começou a estudar os terrenos da City, o primeiro plano idealizado foi a criação de um parque público no local, contudo, pouco tempo depois, o arquiteto constatou que o valor da região dificultaria tal plano, pois a Cia City deixaria de lucrar com futuras vendas de lotes no bairro.

Na década 1920, a City começou a desenvolver o plano de urbanização do Pacaembu, realizando diversas melhorias, entre elas, a canalização do ribeirão homônimo, a abertura da Avenida Pacaembu e a construção de praças, além disso, naquele período, foram comercializados os primeiros terrenos da gleba ${ }^{38}$. Ainda naquela época, percebendo a crescente mobilização esportiva, com destaque para o futebol, a Cia City doou ao governo paulista uma área de 50 mil metros quadrados no bairro do Pacaembu para a construção de um estádio ${ }^{39}$. A autora Cristina Mehrtens revela que até o início dos anos 1930 a área doada permaneceu praticamente abandonada, virando um obstáculo à comercialização dos terrenos da Companhia. Diante disso, a construção do estádio na porção de terra doada tornou-se essencial para os interesses da City, que desejava valorizar a região e acelerar seu desenvolvimento urbano 40

Assim, em 1933, a Cia City decidiu pressionar o governo para iniciar a construção do Estádio do Pacaembu:

"Projeto Pacaembu" foi como o comitê da Cia City denominou sua estratégia. Esta consistia em dois pontos: tornar o município completamente responsável pela construção do prédio e da pavimentação das ruas ao redor, bem como torná-lo um parceiro no financiamento de metade dos custos tołais da construção, estimado em, aproximadamente, 3000 contos. ${ }^{41}$

Outro grupo que se envolveu no projeto foi o Escritório Severo Villares. Isto aconteceu mediante o apoio de membros da City que também faziam parte do Escritório. Depois das negociações entre a Cia City e Arnaldo Dumont Villares ${ }^{42}$ foi estabelecida a parceria para a construção do Estádio do Pacaembu. Alguns dos membros do alto escalão da City, entre eles Arthur du Cros e Gama de Oliveira - representante inglês da City e gerente geral do Brasil, respectivamente 
-, junto com o Escritório Severo Villares, reuniram-se com o Governador de São Paulo, Valdomiro de Lima, e com o Prefeito Theodoro Ramos, estabelecendo os procedimentos para o início do projeto de construção. A Companhia, juntamente com o Escritório, já em dezembro de 1933, apresentou ao governador as plantas do primeiro projeto. Contudo, o desenvolvimento do projeto, que parecia engrenar no início de 1934, não transcorreu de maneira equilibrada, sendo marcado por conflitos até 1938. Nesse período, poder público e iniciativa privada protagonizaram inúmeros desacordos em relação ao projeto do Pacaembu, modificando, anualmente, suas diretrizes, que desagradavam, sobretudo, os membros da Cia City e do Escritório Severo Villares, insatisfeitos com as constantes exigências do governo. A obra teve início apenas no final 1936, ou seja, três anos após a entrega do primeiro projeto. Diante do entrave nas negociações, os custos aumentaram progressivamente, o que preocuva os empreendedores, que culpavam o poder público pela situação exigindo que esse arcasse com os prejuízos ${ }^{43}$.

Segundo Ferreira, dados da biografia de Francisco Prestes Maia evidenciam que a obra do Estádio do Pacaembu estava apenas iniciada em 1938, quando este foi nomeado prefeito, realizando alterações no projeto original:

O primeiro plano feito na gestão Fábio da Silva Prado, em 1936, previa a existência de duas arquibancadas laterais e portões monumentais à frente, como um gigantesco muro ornamental. Esse plano foi substituído com a chegada de Prestes Maia ao poder em 1938, que trouxe consigo um novo conceito arquitetônico, buscando, assim, trazer um caráter monumental à obra, utilizando como principais elementos o concreto armado. ${ }^{44}$

A atuação de Prestes Maia foi fundamental para o desentrave da obra. então empossado prefeito renegociou os contratos com a Cia City e com o Escritório Severo Villares oferecendo boas condições aos empreendedores, provocando uma significativa melhora na relação entre os envolvidos no projeto, como apurou Mehrtens ${ }^{45}$.

Com os conflitos amenizados, as instalações do Estádio Municipal do Pacaembu foram concebidas sob uma área de 75.598 metros quadrados, no entorno das Ruas Itaí, Capivari e Itápolis em conjunção com a Avenida Pacaembu46. O terreno tinha o formato de uma "bacia", sendo propício à construção de grandes arquibancadas pela configuração de seu declive. As arquibancadas norte, leste e oeste eram interligadas, formando uma ferradura. Na porção sul instalou-se a concha acústica, espaço destinado a cerimônias cívicas e espetáculos de arte. Por cima das arquibancadas leste e oeste foram levantadas três torres em cada lado destinadas aos refletores. A fachada "principal" foi erguida defronte a uma grande praça que arrematava o eixo perspectivo da Avenida Pacaembu, e de onde partiam vias laterais que ligavam a região a outros bairros da cidade (Figura 4).
43. Ver Cristina Peixoto Mehrtens (2010, p.142) e Hennan Gessi (2013).

44. Cf. João Pernambuco Ferreira (2008, p.64).

45. Ver Cristina Peixoto Mehrtens (2010, p.156).

46. Reportagem da Revista Acrópole detalha o empreendimento. Ver Acrópole (julho, 1939). 
47. Ver Acrópole (julho, 1939).

48. Ver Acrópole (julho, 1939).

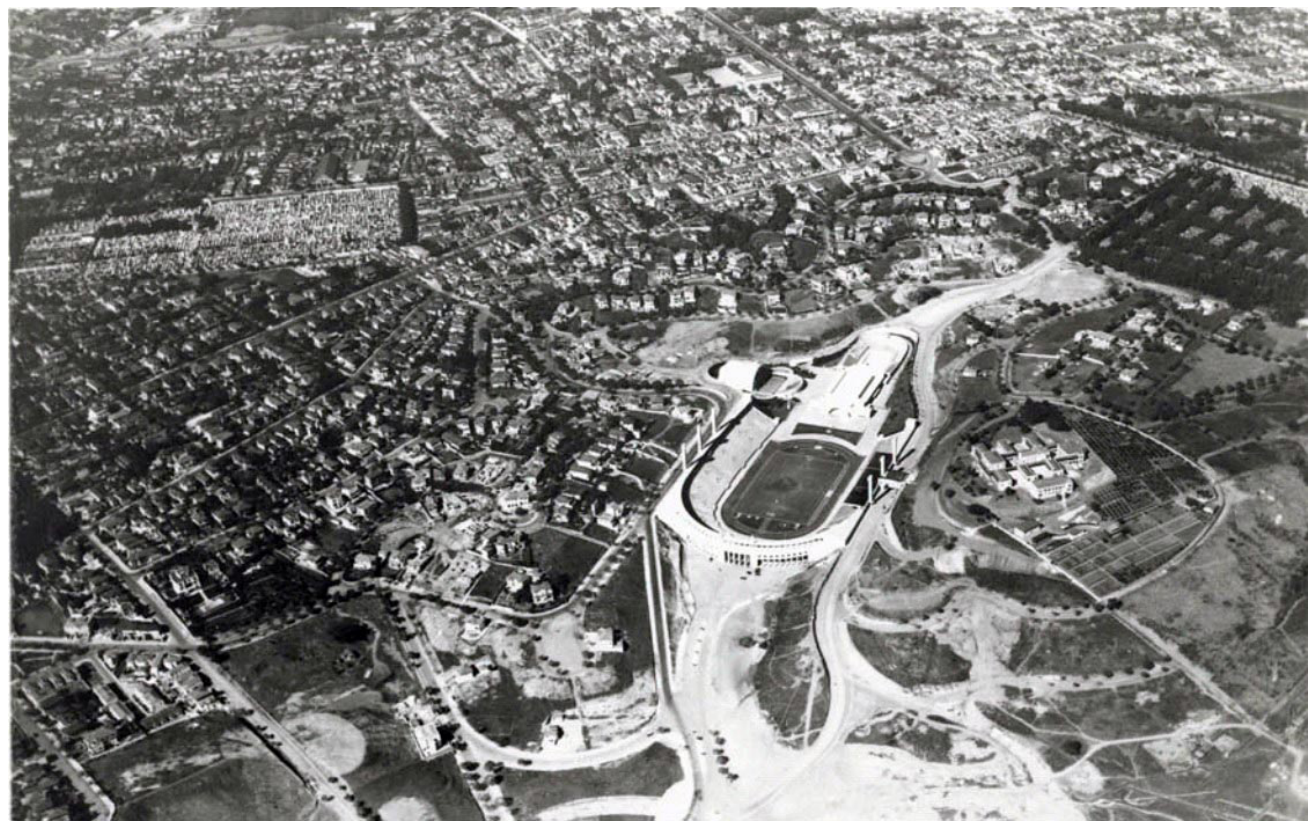

Figura 4 - Vista aérea do bairro do Pacaembu e do Estádio Municipal em obras em finais dos anos 1930. Acervo da Biblioteca da FAU-USP, Fundo Severo \& Villares.

No interior do complexo ainda foram construídos sanitários para o público, vestiários masculinos e femininos, salas de medicina, enfermaria, massagem e área administrativa, túneis de acesso ao campo, três bares com capacidade para 300 pessoas cada um, um restaurante, apartamentos para atletas, salões de esgrima e ginástica e depósitos ${ }^{47}$.

O conjunto esportivo ocupava uma área de 14.476 metros quadrados, tendo, ao centro, um campo de futebol com dimensões de $106 \times 69$ metros, circundado por uma pista de atletismo de 400 metros de comprimento. No contorno da arena central foram construídos o ginásio, a piscina e as quadras de tênis. $\bigcirc$ ginásio abrigava uma área de $60 \times 42$ metros, com capacidade para 3500 espectadores, sendo um espaço destinado às competições de ginástica, hóquei, basquete, vôlei, patinação, boxe e futsal, além de poder receber festas. A piscina foi projetada no formato retangular com a medida de $50 \times 25$ metros e profundidade de 1,5 ×5 metros, onde se localizava a plataforma de salto ornamental. Sua arquibancada também tinha um formato de ferradura e abrigava até 4500 espectadores (Figura 5). Foram construídas duas quadras de tênis, uma fechada e outra ao ar livre. A quadra fechada tinha como medidas 42,70 × 42,87 metros e capacidade para 1500 pessoas, já a quadra ao ar livre também comportava 1500 pessoas e possuía camarotes, bar e vestiários ${ }^{48}$.

Em suma, o estádio possuía cinco entradas e quatro séries de bilheterias no lado norte; nas porções leste e oeste encontravam-se nove entradas de cada 


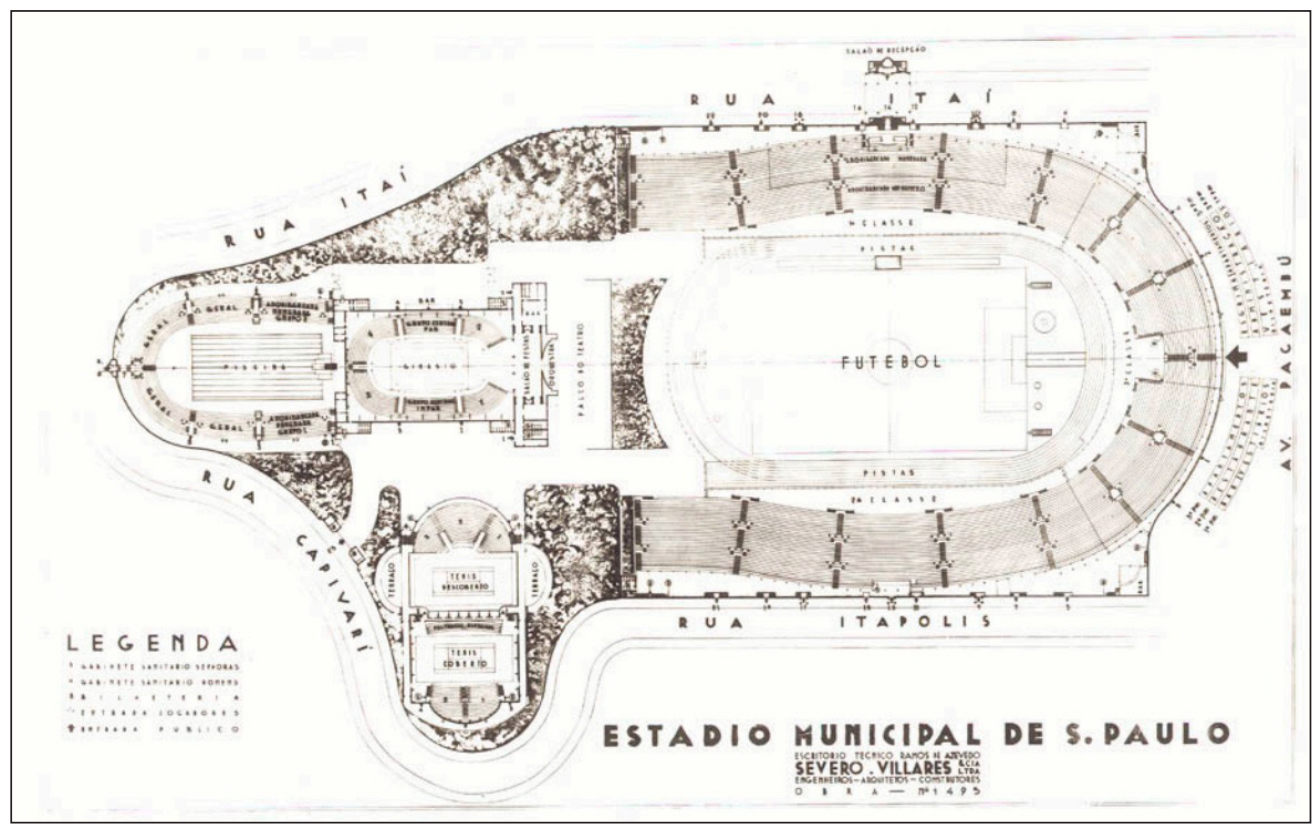

49. Cf. Folha da Manhã (28 abril 1940).

50. Cf. Nicolau Sevcenko (1992, p. 59-60).

Figura 5 - Implantação do Estádio Municipal. Acervo da Biblioteca da FAU-USP, Fundo Severo \& Villares.

lado e diversas séries de bilheterias e, no lado sul, havia uma entrada e duas séries de bilheterias, tendo como capacidade máxima 80 mil pessoas. Como atestava um jornal paulistano, estava ali um estádio que era "o mais moderno e completo de todo o continente sul-americano"49. Uma celebração do progresso em concreto armado.

Arquitetura de Massas: o concreto e o grande público futebolístico

Nicolau Sevcenko, em seu célebre Orfeu Extático na Metrópole, analisa de que maneira o futebol repercutiu na Pauliceia a ponto de poder ser chamado de "febre". Diz o historiador que

Uma avaliação do significado profundo da febre futebolística não pode, entretanto, se circunscrever ao âmbito do cobiçado estádio ou da curta duração das partidas. $\bigcirc$ fenômeno esportivo em geral, futebolístico em particular, é uma manifestação plenamente urbana, que palpita de um modo ou de outro por todos os desvãos da cidade e preenche o tempo ampliado das horas de lazer. Ele é ubíquo na fiscalidade concreta das atitudes e expressões que difunde e onímodo na variedade abstrata dos estados emotivos que desperta e alimenta. A cidade dissipada no caos de um crescimento tumultuoso encontra nele a enfibratura de correntes que organizam pela exaltação. Essas correntes conjugam focos de alinhamentos coletivos que se sustentam pela adesão voluntária e a comutação do entusiasmo em doses cotidianas. A cidade não assiste ao esporte como um episódio isolado e externo: ela the dá vida, corpo e voz - ela não o vê de fora, ela se vê nele. ${ }^{50}$ 
51. Ver Maria Lucia Caira Gitahy (2002).

52. Cf. Marcos Paulo Cereto (2003b, p.9).

53. Cf. Marcos Paulo Cereto (2003a, p.3).

54. Cf. Ibidem
Se, como adverte Sevcenko, a própria compreensão da prática do esporte em São Paulo parece ter sido esmaecida em seu pulsante significado, podemos afirmar que, de igual modo, a relação entre a prática do futebol e o emprego do concreto armado tem sido naturalizada ao longo do século XX. Uma das causas talvez tenha sido o próprio emprego em profusão. Todavia, por meio dos dois estudos de caso deste artigo, podemos perceber que a opção pelo concreto nessas grandes estruturas revela muito do aspecto técnico-cultural inerente ao cenário paulistano da primeira metade do século XX. A presença crescente de engenheiros e grandes empresas da construção civil na resolução dos problemas estruturais desses estádios mostra a difusão e a inovação tecnológica que estava disponível em São Paulo naquele tempo, como bem frisa Maria Lucia Caira Gitahy ${ }^{51}$.

Projetar estádios para a concentração de grandes massas não é algo recente na história das edificações. Os gregos já se valiam desta máxima, conforme expõe Cereto:

A arquitetura de massas na Antiguidade tinha um caráter expresso na permeabilidade de suas faces através de colunatas, diluindo o volume edificado. A caracterização do uso o espetáculo -, configurava o programa da edificação com o espaço destinado a abrigar grandes capacidades de espectadores estabelecendo a relação entre a plateia e o palco. Esta nova configuração diferente dos templos ecumênicos, onde os fieis ficavam em posição de inferioridade em relação a deus, foi definida pela necessidade da visibilidade, fazendo que as arquibancadas surgissem ao longo do palco melhorando, assim, as condições de acomodação do público visitante. A forma em ferradura do templo manifestava a ideia de permeabilidade comum às demais tipologias, uma vez que - estádio estava enterrado na colina. A abertura da ferradura proporcionada pela solução formal dialogava com o entorno da polis grega, estabelecendo uma continuidade espacial. 52

Dessa maneira, ficam claras duas bases de composição da arquitetura esportiva, que seriam replicadas, com poucas alterações, ao longo dos séculos: a relação da cidade, em termos de uso, e da paisagem, em termos de princípios de implantação. Todavia, com o Império Romano e a alteração da relação esportecorpo, a arquitetura esportiva para as massas também foi alterada. Cereto também expõe que "a ruptura na escolha do lote com características específicas para o tema define a principal característica da arquitetura romana", embora o edifício apresente equilíbrio "formal e estético com a cidade" 53 . Interessante é notar, como aponta Cereto, que "os estádios atuais ilustram a utilização deste sistema como um edifício isolado", interiorizando a prática esportiva, e não criando uma relação direta com a cidade ${ }^{54}$. Desta maneira, Cereto consegue definir duas estratégias de projeto traçadas pelos projetistas de estádios e que mostram como Parque Antarctica e Pacaembu encabeçam cada uma delas. Primeiramente, cabe expor a definição de "estrutura aberta", compreendida como aquela em que existe permeabilidade visual a partir das estruturas das arquibancadas revelando a cidade. Por outro lado, 
"estrutura fechada" seria aquela em que ocorre a negação da relação com a cidade, pois a conformação das arquibancadas interioriza a visualidade para o campo $^{55}$.

O Parque Antarctica, em sua primeira organização espacial, demonstrada já no Projeto Spartacus, ancorava-se, como mote projetual, na ideia de estrutura aberta, integrando-se com a paisagem por meio de sua fachada escavada. Contudo, após a realização da expansão pelo Engenheiro Clovis Felipe Olga, bem como da construção das arquibancadas em concreto armado, a estruturação do espaço gerou um nítido ponto focal ao campo, o qual, por si, já era elemento atrativo por ser elevado em relação à pista de corrida lateral. Foi o tempo dos "jardins suspensos" em que até mesmo o curso d'água que interferia nas partidas foi domado e "neutralizado" por obra de engenharia vigorosa.

O Estádio do Pacaembu, embora pareça, em planta, ter intensa ligação com o espaço público, pois tem sua entrada a partir de uma grande praça denominada Charles Miller, a qual coroa o eixo viário da Avenida Pacaembu -, na realidade não a incorpora em termos visuais. Seu sistema de arquibancadas em ferradura, originalmente, era interligado em uma elipse pela presença da Concha Acústica, ao sul. A demolição deste espaço e a construção do sistema de arquibancadas chamado de "Tobogã" interiorizou ainda mais o eixo visual ao campo, negando até mesmo o restante do complexo esportivo. O Pacaembu, ao valer-se da topografia, parece aproximar-se dos estádios gregos, contudo, o fato de ser circundado por vias asfaltadas mostra como o complexo esportivo foi pensado como objeto isolado, cujo eixo perspectivo era a Avenida Pacaembu. $\bigcirc$ jornal $O$ Estado de S. Paulo, pouco tempo antes da inauguração do estádio, exprimiu: "batidas por um sol magnífico, as arquibancadas de concreto rebrilhavam em contraste com o verde terreno do gramado no centro da praça. Um conjunto arquitetônico agradável forma aquela espécie de ferradura incrustada no Vale do Pacaembu"56.

O concreto armado entra em campo tanto no Parque Antarctica quanto no Pacaembu por proporcionarem uma ampliação de público, mas, também, pela possibilidade de adoção de um caráter monumental, quer seja a partir das dimensões das obras, quer seja pelo papel marcante que as edificações desempenhariam sobre os corpos e as mentes. Neste sentido, faz-se importante perceber o que significou o discurso de Prestes Maia quando da inauguração do Pacaembu em abril de 1940:

As linhas sóbrias e belas de sua imponente massa de ferro e cimento não valem, apenas, como expressão arquitetônica, valem como uma afirmação de nossa capacidade de esforço criador do novo regime na execução de seu programa de realizações. Este monumental campo de esportes é, além e, sobretudo, uma obra de são patriotismo, por sua finalidade de cultura física e educação cívica. ${ }^{57}$

Negreiros, comentando esse discurso de Prestes Maia, mostra que
55. Essas definições estão bem sistematizadas em Cereto. Ver Marcos Paulo Cereto (2003a)

56. Cf. O Estado de S. Paulo (24 mar. 1940, p.13).

57. Cf. O Estado de S. Paulo (28 abr. 1940, p. 8) em que consta o discurso de Prestes Maia transcrito na íntegra. 
58. Cf. Plínio José L.C. Negreiros (1998).

59. Cf. O Estado de S. Paulo (26 jun. 1919, p. 6).

60. Cf. Ibidem.

61. Cf. Paulo de Campos. In: O Estado de S. Paulo (24 mar. 1940, p. 13).

62. Cf. O Estado de S. Paulo (27 abr. 1940, p. 10).
Na verdade, o estádio deveria ter um papel maior do que apenas servir como um palco para disputas esportivas; deveria simbolizar a importância que o poder público e setores da sociedade paulista - e também brasileira - davam às atividades físicas, devidamente organizadas e dirigidas pelo Estado. Deveria demonstrar o vigor físico que os paulistas haviam alcançado, como, também, o que poderiam obter. Desta maneira, estava-se frente à construção de um monumento, capaz de expressar concepções acerca dos caminhos que o país precisaria seguir. ${ }^{58}$

Dessa maneira, nota-se que nos anos 1920 e 1930 havia uma plataforma de interferência na cidade como estratégia de revelar a ação da elite e do Estado paulista, respectivamente, por meio das ações no Parque Antarctica e no Pacaembu, que punham a ideia de educação física e do esporte como aliada ao "melhoramento da raça bandeirante", vigorosa e robusta, como o concreto armado, nesses estádios empregados. Esta análise é corroborada, no caso do Parque Antarctica, pela imprensa, e pelos discursos proferidos quando da inauguração do Pacaembu. No caso do Parque Antarctica, reportagem do jornal O Estado de S. Paulo demonstrava "a necessidade inadiável em que estamos de possuir uma grande praça de esportes, para poder acomodar suficientemente as grandes audiências que já conta entre nós o futebol"59. Completava o jornal apontando os "planos" de construção de um grande estádio, sobre os quais a cidade iá tinha tomado ciência: "um na Várzea do Carmo, outro no Parque Antarctica e outro no Vale do Anhangabaú", mas, como apontou o periódico, nenhum deles parecia querer "passar do nanquim para o terreno"60.

Quando, nos anos 1930, a realização do Estádio Municipal tornou-se experiência palpável, os discursos de autoridades e da imprensa revelaram o ideário atrelado à praça esportiva. Paulo de Campos, ao discursar quando da visita da imprensa, em março de 1940, às instalações quase finalizadas do Pacaembu, exprimiu seu prazer em verificar

a grandiosidade da obra - que realmente encerra, majestosamente, em suas entranhas de aço e de cimento armado - o segredo que influirá no corpo e no espírito da mocidade sã para formar a fibra de que se deverá revestir os músculos, a beleza, a têmpera e o caráter da futura raça brasileira. ${ }^{61}$

A solidificação da prática do futebol em São Paulo, desta maneira, além de colocar o concreto armado em visibilidade como material "progressista" e demonstrativo da metrópole paulistana, também o ancorou a um projeto políticoideológico, o qual mostrava que o estado de São Paulo

sem um estádio era realmente incompleto, mas esse estádio não passaria, talvez, de uma obra meramente suntuária não fosse o meticuloso cuidado e o decidido esforço que o poder público está desenvolvendo para colocar a fisicultura no seu verdadeiro plano, pondo-a no mesmo nível de interesse e atenção que desde há muito vinham merecendo a educação intelectual e moral. ${ }^{62}$ 
Assim, a arquitetura desses estádios de futebol é ótimo "índice" para a compreensão político ideológica do século XX em São Paulo, momento em que o futebol entra em campo revelando novos contornos para o lazer, para o uso da cidade, para a estratégia política e, mais, para a relação contundente entre macroestruturas e o emprego do concreto armado num jogo urbano "em que os esgares, rictus, crispações, contorções, toda a variedade infinita de manifestações nervosas que constituem um 'torcimento'" se apresentam ${ }^{63}$.
63. Cf. O Estado de S. Paulo (27 maio 1919, p. 5).

\section{REFERÊNCIAS}

ACAYABA, Marlene Milan. Magnólias 70. Monolito, São Paulo, ano 3, n. 14, 2013.

ALFONSO Chioccarello. Disponível em: <www.inmiamemoria.com/scatole_dei_ricordi/ Chioccarello/Alfonso/>. Acesso em: 25 mar. 2015.

ANTONIO Rocco. Disponível em: <http://www.itaucultural.org.br/aplicExternas/enciclopedia_ IC/index.cfm?fuseaction=artistas_biografia\&cd_verbete $=1124 \& c d$ idioma $=28555>$. Acesso em: 24 mar. 2015.

AS GRANDES festas inaugurais do estádio paulista. O Estado de S. Paulo, São Paulo, 27 abr. 1940, p.10.

BARRY Parker. Disponível em: <http://www.spartacus.schoolnet.co.uk/Barry_Parker.htm>. Acesso em: $1^{\circ}$ abr. 2014.

CAMPOS, Paulo de. Visita ao Estádio Municipal do Pacaembú, O Estado de S. Paulo, São Paulo, 24 mar. 1940, p.13.

CARVAlHO, Maria Cristina Wolff de. Ramos de Azevedo. São Paulo: EDUSP, 1999.

CERETO, Marcos Paulo. Arquitetura de massas: o caso dos estádios brasileiros. Dissertação (Mestrado em Arquitetura) - Universidade Federal do Rio Grande do Sul, Porto Alegre, $2003 a$.

CERETO, Marcos Paulo. Estádios brasileiros de futebol, uma reflexão modernista? In: Seminário DOCOMOMO Brasil, 5, 2003, São Carlos. Anais... São Carlos: DOCOMOMO, 2003 b.

CLUBE Atlético Paulistano. Disponível em: <www.paulistano.org.br/clube-paulistano-historia. html>. Acesso em: 25 mar. 2015.

COSTA, Luiz Augusto Maia. Victor da Silva Freire: a vida, as ideias e as ações de um urbanista de primeira hora, 1869-1951. Cadernos de Pós-Graduação em Arquitetura e Urbanismo da Universidade Presbiteriana Mackenzie, São Paulo, v. 11, n. 2, 2011.

FARAH, Ana Paula. A produção do engenbeiro-arquiteto Francisco de Paula Ramos de Azevedo na província de São Paulo. Dissertação (Mestrado) - Escola de Engenharia de São Carlos, São Carlos, 2003.

FERREIRA, João Fernando. A construção do Pacaembu. São Paulo: Paz e Terra, 2008. 
FRANCISCO Prestes Maia. Disponível em: <http://cpdoc.fgv.br/producao/dossies/JK/ biografias/prestes_maia>. Acesso em: 25 mar. 2015.

GAMBETA, Wilson Roberto. A bola rolou: o Velódromo Paulista e os espetáculos de futebol, 1895-1916. Tese (Doutorado) - Universidade de São Paulo, Faculdade de Filosofia, Letras e Ciências Humanas, São Paulo, 2014.

GESSI, H. Pacaembu: construção e apropriação do espaço, 1933-1963. Trabalho de conclusão de curso (Bacharelado em História) - Universidade Federal de São Paulo, Escola de Filosofia, Letras e Ciências Humanas, Guarulhos, 2013.

GITAHY, Maria Lucia Caira. São Paulo e a tecnologia do concreto, 1899-1948: estudos de história do trabalho como fundamentos sociais da arquitetura e do urbanismo. Tese (LivreDocência) - Universidade de São Paulo, Faculdade de Arquitetura e Urbanismo, São Paulo, 2002.

LEMOS, Carlos A.C. Ramos de Azevedo e seu escritório. São Paulo: PINI, 1993.

MAZZONI, Tomás. A história do futebol brasileiro, 1894-1950. São Paulo: Leia, 1950.

MEHRTENS, Cristina Peixoto. Urban Space and National Identity in Early Twentieth Century São Paulo, Brazil: Crafting Modernity. Nova York: Palgrave Macmillan, 2010.

MILLS, John R. Charles William Miller, 1894-1994. São Paulo: Price Waterhouse, 1996. (Memoriam S.P.A.C.).

NEGREIROS, Plínio José Labriola de C. El Estadio de Pacaembu. Lecturas, Educación Fisica y Deportes, Buenos Aires, ano 3, n.10, maio 1998. Disponível em: <www.efdeportes.com/efd10/ estad2e.htm>. Acesso em: 25 mar. 2015.

NICOLA Rollo. Disponível em: <https://pt.wikipedia.org/wiki/Nicola_Rollo>. Acesso em: 25 mar. 2015.

NOVO estádio municipal. Acrópole, São Paulo, ano 2, n.15, p.1-7, jul. 1939.

O BASQUETE no Brasil. Disponível em: <www.educacaofisica.seed.pr.gov.br/modules/ conteudo/conteudo.php?conteudo=473>. Acesso em: 25 mar. 2015.

O ESTADO de São Paulo. São Paulo, 27 maio 1919, p. 5.

O GRANDE Match Paulistano-Palestra. O Estado de S. Paulo, São Paulo, 26 jun. 1919, p. 6.

PRESTES MAIA, Francisco. Inaugurado o Estádio Municipal do Pacaembu. O Estado de $S$. Paulo, 28 abr. 1940, p. 8.

PRIORE, Mary del; MELO, Victor Andrade de. (Org.). História do esporte no Brasil: do Império aos dias atuais. São Paulo: UNESP, 2009.

RIBEIRO, Anamaria Germano. A história da família Dumont. São Paulo, 1998.

SANTOS NETO, José Moraes dos. Visão do jogo: primórdios do futebol no Brasil. São Paulo: Editora Cosac Naify, 2002. 
SCHPUN, Mônica Raisa. Beleza em jogo: cultura física e comportamento em São Paulo nos anos 20. São Paulo: Editora SENAC, 1999.

SEQUÊNCIA que será observada durante a festa de inauguração do Estádio. Folha da Manhã, São Paulo, 27 abr. 1940, p.19.

SEVCENKO, Nicolau. Orfeu extático na metrópole: São Paulo, sociedade e cultura nos frementes anos 20. São Paulo: Companhia das Letras, 1992.

SOUSA, Diógenes. Parque Antarctica: um patrimônio do lazer na cidade de São Paulo no início do século XX. Trabalho de conclusão de curso (Bacharelado em História) - Universidade Federal de São Paulo, Escola de Filosofia, Letras e Ciências Humanas, Guarulhos, 2014.

SUPER lotação. A Gazeta, São Paulo, 15 maio 1929, p. 9.

THEODORO Ramos. Disponível em: <http://www.sbfisica.org.br/fne/Vol5/Num2/v5n1a10. pdf>. Acesso em: 25 mar. 2015.

VALDOMIRO de Lima. Disponível em: <http://cpdoc.fgv.br/producao/dossies/AEraVargas1/ biografias/valdomiro_lima>. Acesso em: 25 mar. 2015.

VISITA ao Estádio Municipal do Pacaembú. O Estado de S. Paulo, São Paulo, 24 mar. 1940, p. 13.

Artigo apresentado em 26/03/2015. Aprovado em 12/05/2015. 